九州大学学術情報リポジトリ

Kyushu University Institutional Repository

BEES OF THE GENUS PALAEOREZIZA PERKINS

(HYMENOPTERA, COLLETIDAE) OF PAPUA NEW GUINEA COLLECTED BY THE KYUSHU UNIVERSITY EXPEDITION, I

Hirashima, Yoshihiro

https://doi.org/10.5109/2502

出版情報: ESAKIA. 26，pp.5-19，1988-01-25. Entomological Laboratory，Faculty of Agriculture， Kyushu University

バージョン：

権利関係 : 


\title{
BEES OF THE GENUS PALAEORHIZA PERKINS (HYMENOPTERA, COLLETIDAE) OF PAPUA NEW GUINEA COLLECTED BY THE KYUSHU UNIVERSITY EXPEDITION, I $^{12,2)}$
}

\author{
YoshiniRo Hirashima \\ Entomological Laboratory, Faculty of Agriculture, \\ Kyushu University, Fukuoka 812, Japan \\ and \\ Hikosan Biological Laboratory, Faculty of Agriculture, \\ Kyushu University, Hikosan, Fukuoka 824-03, Japan
}

\begin{abstract}
Twelve new species of Palaeorhiza (Hymenoptera, Colletidae), odyneroides, cuprea, heterochroa, latifacies, callima, callimoides, flavipes, tricolor, eumorpha, eugenes, eugenoides and senilis, which were collected by the Kyushu University Expedition, are described from Papua New Guinea.
\end{abstract}

This paper reports one of the results of my study on the bee genus Palaeorhiza Perkins of Papua New Guinea based on the specimens collected by the Kyushu University Expedition which was directed by me in 1982 and 1984. Twelve new species are described in this paper. In addition to our collection, a number of Palaeorhiza specimens collected by me in 1969 for Bishop Museum (the Bishop MuseumNational Geographic Society Expedition to Papua New Guinea and South Pacific Islands) were also studied. All the holotypes of new species will be deposited in the collection of Bishop Museum, Honolulu.

I am grateful to the late Dr. J. L. Gressitt, Bishop Museum and Wau Ecology Institute (WEI), for his help to my study on the New Guinean insects. I am also grateful to Dr. G. A. Samuelson (Bishop Museum), Dr. J. W. Ismay (DPI, Konedobu), Dr. H. Roberts (DPI, Bulolo), Mr. H. Sakulas (WEI) and Mr. N. Kwapena (Wildlife Division, PNG Government) for their help to our field studies in Papua New Guinea.

Contribution from the Entomological Laboratory, Faculty of Agriculture, Kyushu University, Fukuoka (Ser. 3, No. 249).

Contribution from the Hikosan Biological Laboratory, Faculty of Agriculture, Kyushu University, Hikosan (Ser. 3, No. 7).

Partial result of the studies supported by Grants-in-Aid for Overseas Scientific Survey, No. 54041039 (1982) and No. 60043050 (1984) from the Ministry of Education, Science and Culture, to Kyushu University (Prof. Y. Hirashima). 


\section{Key to The species OF Palaeorhiza Described IN THIS PAPER}

1. Head and thorax metallic

- Head and thorax black (sometimes with slight metallic tint) ; rather large to large

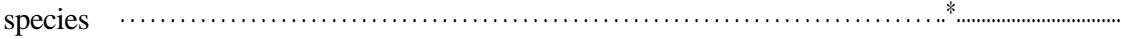

2. Head, thorax and legs with rich yellow markings in both sexes; metasoma with dense hairs; more or less small, robust species

- Head and thorax without yellow marking in female, with a few pale markings on head alone in male

3. Mesoscutum with four longitudinal yellow stripes ; propodeal enclosure with a pair of large, yellow markings ; hairs on metasoma golden, appressed odyneroides

- Mesoscutum and propodeum without yellow marking; hairs on metasoma whitish, longer, suberect

cuprea

4. Head and thorax blue-green, rather dark, weakly shining ; legs black ; metasoma red except basal portion of 1 st tergum blackened; hairs on the apex of metasoma golden.......

- Head and thorax blue-green, strongly shining ; legs red (yellowish red) except fore legs darkened ; metasoma red (apical segments black in callimoides); basal portion of 1st tergum not darkened.....

5. Inner eye margins strongly converging below in both sexes ; malar space very short ; propodeal enclosure punctate on laterobasal portions

- Inner eye margins only slightly converging below ; face broad, especially on lower portion ; malar space and space between eye and clypeus broad ; propodeal enclosure impunctate ; male unknown

6. Metasoma entirely red (yellowish red), shining, with hairs on the apical portion golden ; thorax distinctly convex above and robust as usual

- Metasoma red basally, black apically, with hairs on the black segments fuscous ; thorax slender, not strongly convex above ; wings strongly darkened distally $\ldots . . . \ldots \ldots \ldots . . .$. callimoides

7. Legs yellow ; metasoma black or red

- Legs black ; metasoma entirely red except basal portion of 1st tergum black …............... 9

8. Metasoma black, shining, with slight metallic blue and purple tints

- Metasoma with 1st to 3rd segments red, 4th and following segments black or

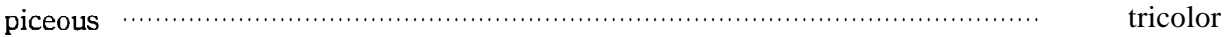

9. Scutellum distinctly convex, with a median, slightly depressed line ; metanotum convex in the middle ; mesoscutum smooth, distinctly shining, with sparse punctures....... eumorpha

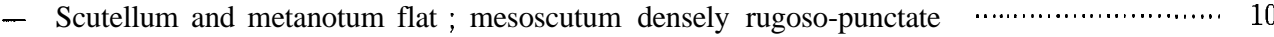

10. Smaller, length about $9 \mathrm{~mm}$ in female ; inner eye margins distinctly converging below ; malar space of female narrow, less than half of basal width of mandible ; thorax with

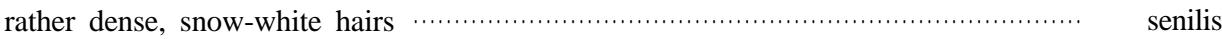

- Larger, length about $10 \mathrm{~mm}$; inner eye margins less converging below ; malar space longer ; hairs on thorax grey or nearly so

11. Malar space about two-thirds as long as basal width of mandible in female, slightly shorter than that in male; clypeus distinctly longitudinally lineolate ; scape of male normal ; lower portion of face with more or less rich yellow markings in male eugenes

- Malar space longer (slightly shorter than basal width of mandible in female, about as long as that in male) ; clypeus less lineolate ; clypeus and supraclypeal area strongly elevated ; scape of male dilated and excavated behind at apex ; face of male with a 
short yellow stripe on clypeus only

eugenoides

Twelve new species described in this paper are divided into five species-groups as shown below. All the species belong to but one subgenus, which will be described as new in a separate paper.

\section{The odyneroides-group}

Two species described below, odyneroides and cuprea, new species, are combined in the odyneroides-group which is distinctive in having the head and thorax distinctly metallic with a rich yellow coloration and the metasoma uniformly cupreous with dense hairs. Exceptions are that the mesoscutum is not marked with yellow in cuprea and the metasoma is braodly yellowish subhyline on the apex of each tergum in odyneroides. The hairy metasoma is one of the most distinctive characters of this group.

\section{Palaeorhiza odyneroides, new species}

This is a medium-sized or rather small, compact, metallic (strongly so on the head and thorax) species having a rich yellow maculation on the head, thorax and legs. The metasoma, which has a strong cupreous reflection when seen from certain angles, is densely covered with short (basally) to long (apically), appressed, golden hairs. The aspect of metasoma recalls certain species of the Vespidae. Hence the name of the species.

Female : Length about or slightly over $7 \mathrm{~mm}$.

Relative head measurements : width, 34.8 ; length, 29.0 ; upper interocular distance, 19.5 ; width of face, 23.5 ; lower interocular distance, 15.8 ; eye length, 24.5 ; length of clypeus, 12.5 .

Head and thorax dark blue-green (including propodeal enclosure), shining, with yellow markings or portions as follows : large and long mark on paraocular area, longitudinal broad mark on clypeus, mark on lower portion of supraclypeal area, longitudinal mark on upper portion of supraclypeal area and frons (notched or bified below), long and rather broad band on genal area along eye margin (thus, eye surrounded by yellow except at both extremities), band on vertex along the preoccipital carina, broad band on pronotum, four lines on mesoscutum, mark on axilla, broad mark on lateral portion of scutellum, a pair of large marks on propodeal enclosure, large mark on tubercle, large mark on preepistemum behind tubercle, and transverse rnark on upper portion of metepistemum ; flagellum reddish brown beneath ; tegula brown; wings dusky with slight yellowish tint ; stigma and veins pale yellowish brown (not darkened) ; legs piceous with purple tint, with large yellow markings on all tibiae ; each metasomal tergum broadly blackened basally, reddened apically, with slight brassy reflection ; sterna blackish brown.

Inner eye margins distintly converging below except upper portions ; malar space very narrow anteriorly, slightly widened posteriorly ; space between eye and clypeus broader than malar space, about as broad as width of median ocellus which is smaller than posterior ocelli ; clypeus and lower portion of supraclypeal area well convex, upper portion of the latter broad, slanting above, not dilated ; upper portion of head behind ocelli strongly slanting posteriorly ; ratio of ocellocular distance to postocellar distance to ocelloccipital distance as $5.5: 4.0: 4.5$. Mesoscutum well convex ; scutellum and metanotum rather flat; propodeal enclosure large, largely dorsal, nearly triangular with lateral margins slightly curved outwardly ; precoxal carina on lower portion of mesepistenum weak. First metasomal tergum rather short, broad; 2nd tergum well convex at the middle, depressed at the base.

Clypeus with sparse, rather distinct punctures ; colored portion of paraocular area smooth, 
shining, with sparse, very small punctures; frons, upper portion of paraocular area and vertex densely rugoso-punctate; mesoscutum densely, rather strongly rugoso-punctate ; scutellum densely punctate, punctures much weaker than those on mesoscutum; propodeal enclosure microscopically shagreened, weakly shining, punctate on yellow-colored portions ; pre- and meso-episternum densely punctate, punctures much weaker than those on mesoscutum ; 1st tergum very densely, finely punctate; 2nd also very densely punctate, punctures slightly larger than those on 1st; terga without glabrous apical margins.

Hairs on head and thorax rather long, more or less dense, fulvous or golden, shining ; metepisternum and lateral face of propodeum densely covered with short grey hairs ; 1st and 2nd terga with short, 3rd and following terga with longer, dense, appressed, golden hairs ; no dark hair on the apex of metasoma.

Male : Relative head measurements : width, 31.8 ; length, 26.0 ; upper interocular distance, 17.5 ; width of face, 19.0 ; lower interocular distance, 9.5 ; eye length, 22.5 ; length of clypeus, 10.5

Differs from female as follows : Eyes large, inner eye margins very strongly converging below ; malar space narrower and nearly obsolescent ; clypeus and supraclypeal area nearly flat ; scape short; flagellum long, 1st segment small, about as long as broad, 2nd broader than long, 3rd longer than broad and a little shorter than 1st and 2nd combined, 4th slightly longer than 3rd ; legs rather robust, with fore tarsi elongate ; 1st tergum flat dorsoposteriorly, low ; 2nd tergum distinctly convex medially and distinctly depressed at the base ; metasomal sterna unmodified ; hairs on head, thorax and metasoma longer and paler (whitish) and those on lateral face of propodeum much sparser than in female.

Type Material : Holotype female (BISHOP 13877) and 1 paratype female, Mt. Kaindi, 2,360 m, 1112. ix. 1969 (Y. Hirashima) ; 2 paratopotype females and 1 paratopotype male, on Evodia, 24-25. ix. 1969 (Y. Hirashima) ; 1 paratype female, Bulldog Road, 19-29 km S of Wau, Morobe District, 2,500 m, 28. v. 1962 (J. Sedlacek) ; 1 paratopotype female, 14-26. vii. 1982 (Y. Hirashima).

Distribution : Papua New Guinea (Mt. Kaindi).

\section{Palaeorhiza cuprea, new species}

This is a close relative of odyneroides, new species, but is easily separable from it by the absence of the yellow markings on the mesoscutum and propodeal enclosure, the presence of the yellow markings on the malar space and mandible, and the unicolored metasoma. In addition, the hairs on the metasoma are longer and paler, those on the lateral face of propodeum much sparser and the punctures on the side of thorax much stronger than in odyneroides.

Female : Length similar to odyneroides.

Relative head measurements : width, 33.0 ; length, 28.0 ; upper interouclar distance, 20.0 ; width of face, 22.2 ; lower interocular distance, 15.5 ; eye length, 22.5 ; length of clypeus, 11.8 .

Head and thorax cupreous with brassy tint, shining, with following pale yellow markings : large mark on mandible (absent in odyneroides), long diverse $\mathrm{T}$ on clypeus, subtriangular mark on lower portion of supraclypeal area, small mark on upper portion of the latter, broad mark surrounding eye which is interrupted above (thus, malar space yellow in cuprea, black in odyneroides), band on pronotum, mark on axilla, small mark or spot on scutellum next to axilla, spot on tegula (no mark on tegula in odyneroides), mark on tubercle, small mark on episternum behind tubercle and transverse mark on metepisternum above ; flagellum reddish brown beneath ; wings distinctly yellowish ; legs piceous with cupreous or brassy tint, with large, pale yellow markings on all tibiae ; metasoma piceous, with distinct brassy tint.

Inner eye margins distinctly converging below; malar space broader than in odyneroides, about 
one-half as broad as basal width of mandible ; frons between supraclypeal area and mid ocellus more convex and more strongly coarsely rugoso-punctate than in odyneroides; mesoscutum and scutellum more strongly punctate than in odyneroides; propodeal enclosure more shagreened and duller than in odyneroides, with a median, depressed line ; propodeum outside enclosure strongly punctate ; lateral face of propodeum with hairs much sparser than in odyneroides ; pre- and meso-episternum smooth, strongly shining, with strong, rather sparse punctures ; metasoma punctate nearly as in odyneroides, with hairs longer, paler, whitish at the apex,

Male : Relative head measurements : width, 28.5 ; length, 24.0 ; upper interocular distance, 17.0 ; width of face, 18.0 ; lower interocular distance, 11.0 ; eye length, 20.8 ; length of clypeus, 10.0.

Differs from female as follows : Yellow marking on clypeus shorter, absent on upper portion ; mark on lower portion of supraclypeal area absent and that on upper portion smaller and sometimes absent ; all basitarsi often with pale yellow markings basally ; inner margins of eyes more strongly converging below so that face distinctly narrower below ; malar space narrower, very narrow anteriorly, widened posteriorly ; supraclypeal area well convex ; metasomal sterna unmodified or with a pair of weak, posteriorly converging, glabrous elevations on 3rd alone or 3rd and 4th in larger specimens.

Type materias : Holotype female (BISHOP 13878), 3 paratype females and 6 paratype males, Keglsugl, 2,700 m, Mt. Wilhelm, 12. viii. 1969 (Y. Hirashima) ; 2 paratopotype females, 2,600 m, 1-2. viii. 1982 (Y. Hirashima).

Distribution : Papua New Guinea (Mt. Wilhelm).

\section{The heterochroa-group}

Two species described below, heterochroa and latifacies, new species, are tentatively combined into the heterochroa-group which is distinctive in having the head and thorax strongly metallic, the legs black and the metasoma red. No pale marking is present on the head and thorax in the female, but a few yellow markings on the head of the male. The basal portion of the 1st metasomal tergum is black.

\section{Palaeorhiza heterochroa, new species}

This is a distinctive species which is easily recognizable by its unique coloration and the presence of punctures on the propodeal enclosure.

Female : Length about $8 \mathrm{~mm}$.

Relative head measurements : width, 36.0 ; length, 29.5 ; upper interocular distance, 20.0 ; width of face, 24.0 ; lower interocular distance, 15.0 ; eye length, 25.5 ; length of clypeus, 12.5 .

Head and thorax metallic blue-green including propodeal enclosure and tubercles; head and thorax with purple reflection when seen from certain angles; mandibles, labrum and apical margins of clypeus narrowly black ; antennae piceous, flagellum brownish beneath ; legs black ; wings distinctly darkened, stigma, veins and tegulae deep brown or blackish ; metasoma entirely red except basal portion of 1st tergum black with metallic tint ; no pale marking on any part of body.

Inner margins of eyes distinctly converging below except upper portions ; space between clypeus and eye very narrow, narrower than diameter of mid ocellus ; malar space very narrow anteriorly, slightly widened posteriorly; upper portion of supraclypeal area broad, nearly flat or slightly elevated ; upper portion of head behind ocelli distinctly slanting posteriorly. Collar of pronotum not highly elevated ; scutellum broad, nearly flat ; metanotum also flat ; propodeal enclosure large, triangular, slanting. First metasomal tergum not strongly convex ; 2nd tergum well convex in the 
middle, deeply depressed at the base.

Head slightly shining or rather dull, densely and microscopically shagreened (including clypeus) ; punctures on clypeus weak and sparse, those on upper portion of supraclypeal area dense and rather distinct, those on frons weaker ; mesoscutum densely rugoso-punctate, punctures somewhat roughened; punctures on scutellum also dense but weaker; propodeal enclosure microscopically sha greened, punctate on latero-basal portions; pre- and meso-episternum densely punctate, but punctures weaker and a little sparser than those on mesoscutum ; 1st tergum densely, weakly punctate, without glabrous apical margin ; 2nd tergum with punctures larger, sparser; 3rd tergum coarsely punctate, punctures larger (but not very stronger) than those on 2nd ; 2nd and 3rd terga also without glabrous apical margins.

Hairs on head not conspicuous, whitish ; those on thorax short, not dense, white ; those on apical portion of metasoma golden.

Male : Relative head measurements : width, 36.0 ; length, 30.0 ; upper interocular distance, 19.5 ; width of face, 22.0 ; lower interocular distance, 12.0 ; eye length, 26.0 ; length of clypeus, 12.0.

Differs from female as follows : Head and legs with pale yellow markings as follows : short line on space between clypeus and eye below, apical transverse line on clypeus, spot on labrum, line on mandible, large mark on anterior face of fore tibia and small marks on apices of fore and mid femora and base of mid tibia. Eyes large (inner eye margins strongly converging below, as in female, malar space very narrow, and space between clypeus and eye also very narrow) ; scape nearly normal ; flagellum with 1st segment elongate (about 1.5 times as long as broad), 2nd broader than long, 3rd about as long as 1st ; 4th sternum with a pair of weak, glabrous elevations ; apical fringe of hairs on 5th sternum short, inconspicuous; hairs on apical portion of metasoma golden like female but sometimes with sparse brownish hairs.

TyPe MAterial : Holotype female (BISHOP 13879), 1 paratopotype female and 9 paratopotype males, Mt. Kaindi, 2,360 m, near Wau, Morobe District, on Rubus sp., 24-25. ix. 1969 (Y. Hirashima) ; 2 paratopotype females, 14-26. vii. 1982 (Y. Hirashima).

Distribution : Papua New Guinea (Mt. Kaindi).

\section{Palaeorhiza latifacies, new species}

So far as the coloration of the body is concerned, this new species is very similar to heterochroa, new species, but is separated from the latter in having the malar space longer and the face much broader on the lower portion. Hence the name of this species.

Female : Length about or slightly over $8 \mathrm{~mm}$.

Relative head measurements : width, 36.5 ; length, 30.5 ; upper interocular distance, 20.0 ; width of face, 24.0 ; lower interocular distance, 19.0; eye length, 24.8 ; length of clypeus, 12.5 ; length of malar space in the middle, 3.0.

Head and thorax metallic blue-green, with slight purple tint when seen from certain angles, slightly darker than in heterochroa; antennae brown or more darker; legs piceous with metallic (purple and blue) reflection ; wings dusky all over ; metasoma red except basal portion of 1 st tergum blackened (metasoma much yellowish in the holotype) ; no yellow marking on any part of body.

Inner eye margins only slightly converging below except upper portions ; malar space long, about two-thirds as long as basal width of mandible; space between eye and clypeus also broad, much broader than diameter of mid ocellus ; clypeus rather flat ; supraclypeal area also flat on upper portion ; ocelli rather small ; ratio of ocellocular distance to postocellar distance to ocelloccipital distance as $5.8: 3.5: 6.0$. Collar of pronotum thin, rather low ; scutellum slightly convex, especially on apical portion ; metanotum also slightly convex ; propodeal enclosure large, well convex, with lateral 
margins rounded (convex outwardly). Wings with stigma and 2nd submarginal cell large. Legs slender as usual. Metasoma similar to heterochroa.

Head lineolate and distinctly punctate ; punctures on clypeus indistinct ; mesoscutum densely and strongly rugoso-punctate; punctures on scutellum dense, weaker than those on mesoscutum ; propodeal enclosure shining, microscopically lineolate, impunctate as usual ; metasoma finely and rather densely punctate ; punctures on 3rd tergum much weaker than in heterochroa ; apical margin of 1 st tergum narrowly impunctate.

Hairs sparse, not conspicuous, white ; those on apical portion of metasoma golden.

TYPE MATERIAL : Holotype female (BISHOP 13880), Mt. Kaindi, 2,388 m, Morobe District, 14-26. vii. 1982 (Y. Hirashima); 1 paratype female, Keglsugl, 2,700 m, Mt. Wilhelm, Chimbu District, 12. viii. 1969 (Y. Hirashima).

Distribution : Papua New Guinea (Mt. Kaindi, Mt. Wilhelm).

\section{The callima-group}

Two species described below, callima and callimoides, are placed in the callima-group which is similar to the heterochroa-group in having the head and thorax metallic and the metasoma red, but is separable by having the legs red and the 1st metasomal tergum not blackened basally.

\section{Palaeorhiza ca llima, new species}

This is a beautifully colored species having the head and thorax shining blue-green and the metasoma and legs red. Hence the name of this species (a Greek adjective kallimos, beautiful).

Female : Length about $8 \mathrm{~mm}$.

Relative head measurements : width, 36.5 ; length, 30.0 ; upper interocular distance, 19.0 ; width of face, 24.0 ; lower interocular distance, 17.0 ; eye length, 25.5 ; length of clypeus, 12.5 .

Head and thorax shining (the face especially so), metallic blue-green, with slight purple reflection when seen from certain angles; propodeal enclosure shining purple; wings dusky except basal portions yellowish ; legs yellow (or may be red) except fore legs broadly darkened ; metasoma yellow or reddish yellow all over; no pale marking on any part of body except white mark on the basal portion of hind tibia anteriorly (this white marking rarely absent).

Inner eye margins distinctly converging below ; malar space narrow (but distinct), less than half as long as basal width of mandible in the middle, broadened posteriorly ; space between eye and clypeus slightly broader than anterior portion of malar space, narrower than in Zatifacies, much broader than in heterochroa ; clypeus nearly flat, with three, weak, longitudinal elevations ; supraclypeal area more or less distinctly convex in the middle, upper portion slanting, not highly elevated ; ocelli, especially posterior ones, rather large ; upper portion of head behind ocelli distinctly slanting ; ratio of ocellocular distance to postocellar distance to ocelloccipital distance as $5.0: 3.5: 5.0$. Mesoscutum well convex ; scutellum convex especially on basal portion (near mesoscutum) ; metanotum nearly flat ; propodeal enclosure large, slanting, with lateral margins slightly curved outwardly. Wings with stigma and 2nd submarginal cell large. Hind tibia more or less thick basally when seen from above. Metasoma well convex, very shining.

Head in front shining, with microscopical sculpture, punctures very weak and sparse even on frons and vertex ; mesoscutum shining, densely subrugoso-punctate, punctures not strong ; scutellum densely and rather coarsely rugoso-punctate, punctures about as coarse as those on posterior portion of mesoscutum ; propodeal enclosure nearly smooth, shining; pre- and meso-episternum densely punctate, punctures much weaker than those on mesoscutum; metasomal terga smooth, strongly 
shining, with sparse, weak punctures ; apical margins of 1st and following terga broadly impunctate.

Hairs not dense, not conspicuous; those on head slightly brownish, those on thorax grey and slightly brownish at sides, those on legs pale, bright, and those on apical portion of metasoma golden.

Male : Relative head measurements : width, 33.5 ; length, 30.5 ; upper interocular distance, 17.5 ; width of face, 21.0 ; lower interocular distance, 14.2 ; eye length, 24.0 ; length of clypeus, 13.0 ; length of malar space in the middle, 3.5.

Differs from female as follows: Head and legs with white markings or portions as follows: apical mark on clypeus, labrum, most part of mandible, anterior face of scape, anterior face of fore tibia, small basal mark on mid tibia anteriorly and larger mark on anterior face of hind tibia ; lower portion of thorax largely red; propodeum slightly reddened (with metallic tint as in female) ; malar space broad, slightly shorter than basal width of mandible; space between clypeus and eye also broad, nearly as broad as malar space; scape rather elongate, slender; flagellum long, with 1st segment small, a little longer than broad at apex, 2nd broader than long, 3rd a little longer than broad, and 4th and following segments longer than broad; clypeus long, narrow ; supraclypeal area slightly convex in the middle; precoxal carina stronger than in female; 2nd tergum well convex in the middle and rather distinctly concave at the base as usual for the male of Palaeorhiza; apical fringe of curled hairs on 5th sternum long; hairs on apical portion of metasoma, including the fringe stated above, golden as in female.

TYPE MATERIAL: Holotype female (BISHOP 13881) and 2 paratopotype females, Daulo Pass, 2,400 m, $40 \mathrm{~km}$ W of Goroka, 14. viii. 1982 (Y. Hirashima) ; 2 females and 1 male, Keglsugl, 2,700 m, Mt. Wilhelm, Chimbu District, on Rubus sp., 10-11. viii. 1969 (Y. Hirashima).

Distribution : Papua New Guinea (Daulo Pass, Mt. Wilhelm).

\section{Palaeorhiza callimoides, new species}

This is placed in the callima-group because of similarity of the coloration (except the apical portion of the metasoma black), but is distinctive in having the thorax slenderer and longer than callima.

Female : Length about or slightly less than $8 \mathrm{~mm}$, rather slender.

Relative head measurements : width, 35.0 ; length, 29.0 ; upper interocular distance, 18.5 ; width of face, 22.5 ; lower interocular distance, 15.5 ; eye length, 24.2 ; length of clypeus, 12.0.

Head and thorax shining metallic blue-green with slight bronz reflection; propodeal enclosure also shining blue-green (black-purple in callima); antennae brown or piceous, flagellum beneath yellowish brown; legs yellowish red except fore legs darkened (fore femur with metallic blue-green reflection) ; tegula with metallic blue-green tint ; wings strongly dusky except basal portions yellowish ; metasoma with three basal segments red, three apical segments black with purple reflection.

Inner margins of eyes distinctly converging below; malar space narrow anteriorly, well broadened posteriorly, less than one-half as long as basal width of mandible in the middle ; oculoclypeal distance longer than malar space, slightly shorter than width of mid ocellus ; clypeus weakly convex, rather flat ; supraclypeal area also flat on lower portion, slanting and not dilated on upper portion ; posterior ocelli on the top of head, and the space behind them strongly slanting ; ratio of ocellocular distance to postocellar distance to ocelloccipital distance as $4.9: 3.5: 5.0$. Thorax more or less long, rather flat dorsally when seen from the side ; scutellum and metanotum flat ; propodeal enclosure large, gently slanting, lateral margins slightly curved outwardly. Metasoma usual. Wings with stigma and 2nd submarginal cell large.

Clypeus densely, microscopically shagreened, nearly impunctate ; lower portions of paraocular area and supraclypeal area similar to clypeus ; frons and vertex with weak, rather sparse punctures. 

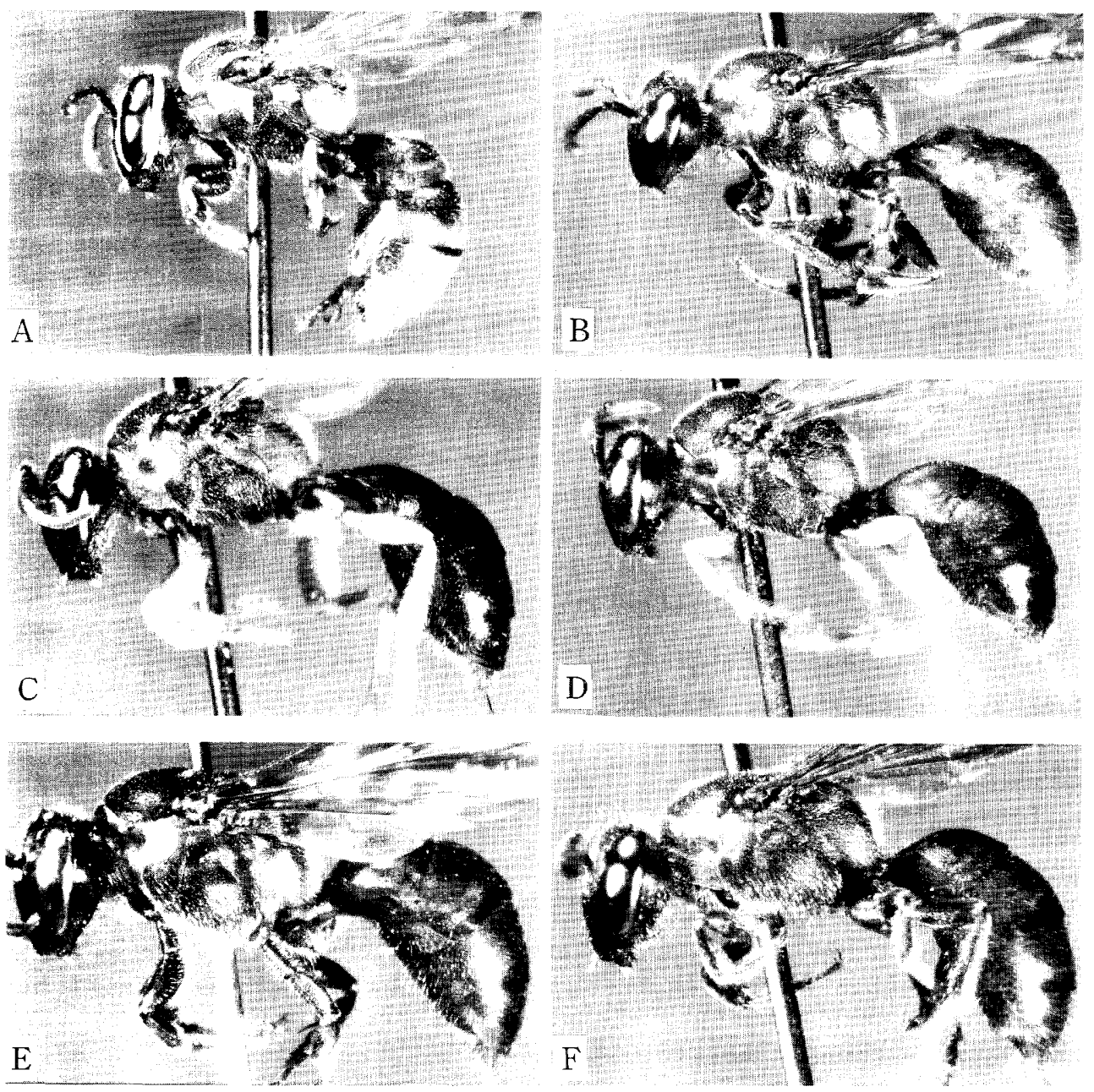

Fig. 1. New species of Palaeorhiza, females. A : odyneroides, B : heterochroa, C : flavipes, D : tricolor, E : eumorpha, F: eugenes.

Mesoscutum densely, rather strongly rugoso-punctate; scutellum as in mesoscutum but punctures weaker; propodeal enclosure nearly smooth or microscopically lineolate; sides of thorax very densely punctate, punctures much weaker than those on mesoscutum. Metasoma with 1st tergum densely and weakly punctate, 2nd and 3rd more strongly punctate; apical impunctate margins of terga (including 1st) broad.

Hairs on head and thorax sparse, white or whitish, not conspicuous; hairs on three apical segments black, and those on 2nd and 3rd sterna also black.

Male : Relative head measurements : width, 31.0 ; length, 27.5 ; upper interocular distance, 16.0 ; width of face, 19.8 ; lower interocular distance, 10.0 ; eye length, 23.2 ; length of clypeus, 11.5.

Differs from female as follows :Scape white or whitish in front; anterior face of hind tibia 
whitish basally; apical portion of 3rd tergum and most part of 3rd sternum blackened ; inner eye margins very strongly converging below except upper portions; malar space narrow (relatively as broad as in female) ; flagellum with two basal segments small, broader than long, 4th and following segments longer than broad; metasomal sterna unmodified ; hairs on apex of metasoma whitish (but hairs on blackened portions of metasoma black or nearly so as in female).

TYPE MATERIAL: Holotype female (BISHOP 13882) and 3 paratopotype males, Mt. Kaindi, 2,388 m, Morobe District, 14-26. vii. 1982 (Y. Hirashima); 1 paratopotype female, 14-26. vii. 1982 (0. Tadauchi).

Distribution : Papua New Guinea (Mt. Kaindi).

\section{The flavipes-group}

Two species described below, flavipes and tricolor, new species, are included into the flavipesgroup which is characteristic in having the head and thorax black (with slight metallic reflection) and the legs yellow. The metasoma is black in flavipes and red in tricolor, with a slight metallic tint in both species. The males of these species are distinctive in having the mesepisternum convex conically in the middre below.

\section{Palaeorhiza flavipes, new species}

This rather large species is easily recognizable by its unique coloration; the head, thorax and metasoma black and legs yellow. Hence the name of the species, The 1st metasosmal tergum is more or less long, and gently narrowed toward the base, showing a similar aspect to the members of the subgenus Sphecogaster Hirashima.

Female : Length 8-9.5 mm.

Relative head measurements : width, 40.0 ; length, 34.0 ; upper interocular distance, 19.5 ; width of face, 25.5 ; lower interocular distance, 19.5 ; eye length, 28.8 ; length of clypeus, 14.5 .

Head, thorax and metasoma black, without yellow marking; thorax often with very slight metallic (brassy and purple) tint; metasoma often with slight metallic (dark blue, brassy and purple) reflection ; legs entirely yellow except fore coxa black, and hind coxa and fore and middle trochanters broadly brownish ; fore tarsus, especially distitarsi often slightly brownish ; wings dusky, especially on distal margins ; tegula brownish.

Inner eye margins slightly converging below ; malar space about one-half as long as basal width of mandible in the middle, slightly broadened posteriorly ; space between clypeus and eye broader than malar space, as broad as mid ocellus which is very slightly smaller than posterior ocelli ; clypeus rather flat, ; supra-clypeal area well convex in the middle, upper portion more or less abruptly slanting above, well formed ; ocelli rather large; ratio of ocellocular distance to postocellar distance to ocelloccipital distance as $5.0: 3.5: 5.5$; upper portion of head behind ocelli strongly slanting posteriorly. Collar of pronotum low; mesoscutum and scutellum well convex ; propodeal enclosure large, slanting but almost all dorsal, nearly triangular ; precoxal carina on mesepisternum strong. Wings with stigma and 2nd submarginal cell large, the latter receiving the 1 st recurrent vein near the middle of cell. Legs more or less robust. Metasoma with 1 st tergum as described above ; 2nd distinctly convex at the middle, depressed at the base.

Head shining, nearly smooth, with microscopical punctures and lineolation; mesoscutum rather strongly, densely rugoso-punctate, slightly less shining than in head ; mesoscutum also densely rugosopunctate, shagreened, duller; metanotum well punctate; propodeal enclosure nearly smooth or microscopically lineolate; propodeum outside enclosure densely rugoso-punctate ; upper portion of lateral face of thorax weakly, densely punctate ; metasoma smooth, strongly shining, with weak, 
sparse punctures; apical margins of 1 st and following terga broadly glabrous.

Hairs very sparse on head, more or less distinct and whitish on thorax ; hairs on lateral face of propodeum short, dense, grey ; hairs on metasoma sparse, those on the apical portion brownish.

Male : Relative head measurements : width, 35.0 ; length, 32.0 ; upper interocular distance, 16.5 ; width of face, 21.0 ; lower interocular distance, 16.0 ; eye length, 25.0 ; length of clypeus, 13.5 ; length of malar space in the middle, 4.0.

Differs from female as follows : Face elongate ; malar space elongate, about equal to basal width of mandible; space between clypeus and eye also very broad, slightly narrower than malar space ; scape rather long; flagellum with 1 st segment longer than broad, longer than 2nd which is braoder than long, 3rd about as long as broad, 4th about as long as 1 st ; lower portion of mesepisternum convex medially; 3rd sternum with a U-shaped ridge medially ; 5 th sternum with apical fringe of long, curled, brownish hairs.

Type material : Holotype female (BISHOP 13883), Mt. Kaindi, 2,360 m, on Evodia, 23. viii. 1969 (Y. Hirashima) ; 12 paratopotype females and 4 paratopotype males, on Evodia, viii-ix. 1969 (Y. Hirashima) ; 11 paratopotype females and 2 paratopotype males, vii-viii. 1982 (Y. Hirashima).

Distribution : Papua New Guinea (Mt. Kaindi).

\section{Palaeorhiza tricolor, new species}

This is a medium-sized, robust species which is distinctive in having the head and thorax black, the legs yellow and the metasoma red (black on the apical portion). Hence the name of the species. Morphologically, this is not much differentiated from callima, new species, except the characters of the underside of thorax in the male.

Female : Length about or slightly less than $8 \mathrm{~mm}$.

Relative head measurements : width, 38.2 ; length, 32.0 ; upper interocular distance, 18.0 ; width of face, 24.0 ; lower interocular distance, 18.0 ; eye length, 27.0 ; length of clypeus, 13.0.

Head and thorax black, the latter with very slight metallic purple tint ; wings broadly dusky, basal portion slightly paler ; legs yellow except coxae and trochanters brownish ; metasoma with three basal segments red and three apical segments black. No pale markings on head and thorax.

Inner eye margins rather distinctly converging below ; malar space nearly as long as in callima; clypeo-ocular distance longer than malar space, a little broader than width of mid ocellus which is smaller than posterior ocelli ; clypeus with three longitudinal ridges (although very weak) ; supraclypeal area similar to callima; upper portion of head behind ocelli distinctly slanting ; ratio of ocellocular distance to postocellar distance to ocelloccipital distance as $4.0: 3.8: 6.0$. Mesoscutum and scutellum well convex ; metanotum rather flat; propodeal enclosure large, slanting, nearly triangular, lateral margins only slightly curved outwardly ; precoxal ridge or carina distinct. Legs more or less robust. Metasoma well convex as usual ; 1st tergum rather large.

Head nearly smooth or microscopically lineolate, with very weak and sparse punctures ; mesoscutum densely and rather strongly rugoso-punctate; scutellum also densely rugoso-punctate, but punctures weaker than those on mesoscutum ; propodeal enclosure microscopically lineolate, well shining; propodeum lateral to enclosure densely punctate, punctures small, nearly as strong as those on upper portion of pre- and meso-episternum. Metasoma with 1st tergum rather densely and weakly punctate, 2nd and 3rd more strongly punctate ; impunctate apical margin narrow (but well noticeable) on 1st, broad and distinct on 2nd and 3rd.

Hairs sparse, short, not conspicuous on head and thorax ; hairs on black metasomal segments fulvous ; not dark hairs on the apex of metasoma.

Male : Relative head measurements : width, 35.5 ; length, 30.5 ; upper interocular distance, 16.5; 
width of face, 21.0 ; lower interocular distance, 15.0 ; eye length, 26.0 ; length of clypeus, 13.5 ; length of malar space in the middle, 2.8 .

Differs from female as follows : Large mark on lower half of clypeus, longitudinal mark on lower portion of supraclypeal area, mark on labrum, short stripe on mandible, and basal portion of anterior face of scape white; propodeum very slightly reddened (therefore slightly piceous); apical half of 3rd tergum and most part of 3rd sternum blackened; malar space broad, more than half of basal width of mandible in the middle ; clypeo-ocular space also broad, about as broad as mid ocellus ; flagellum not long, 1st segment slightly longer than broad, 2nd about as long as broad (or slightly broader than long), 3rd about as long as 1st, 4th longer than 3rd ; 3rd sternum with a pair of inwardly curved ridges; 4th sternum with similar but much weaker and shorter ridges medially; metasomal terga with punctures much weaker than in female.

Type material : Holotype female (BISHOP 13884) and 1 paratopotype female, Bulldog Road, 2,600 m, $35 \mathrm{~km} \mathrm{SE}$ of Wau, Morobe Province, 25-27. vii. 1969 (Y. Hirashima) ; 1 paratype female, Mt. Kaindi, 2,388 m, Morobe District, 14-26. vii. 1982 (Y. Hirashima) ;1 paratype male, the same locality as above, 17. viii. 1982 (Y. Hirashima).

Distribution: Papua New Guinea (Mt. Kaindi).

\section{The eumorpha-group}

Four species described below, eumorpha, eugenes, eugenoides and senilis, are placed in the eumorpha-group which is distinctive in having the body large, the head, thorax and legs black and the metasoma red. They are superficially very close to one another, and are distinguished primarily by the shape of the head, the length of the malar space, and the density of the punctures on the head and thorax. In eumorpha alone the scutellum and metanotum are convex, and in senilis the hairs on the thorax are snow-white.

The four species is placed in the following order so far as the number of specimens in Bishop Museum and Kyushu University is concerned ; eumorpha (93 specimens), eugenes (23), eugenoides (8) and senilis (2).

\section{Palaeorhiza eumorpha, new species}

Female : Length about or slightly less than $10 \mathrm{~mm}$.

Relative head measurements : width 41.5 ; length, 37.0 ; upper interocular distance, 21.2 ; width of face, 26.5 ; lower interocular distance, 21.2 ; eye length, 28.5 ; length of clypeus, 16.5 ; length of malar space in the middle, $3.8-4.0$.

Head and thorax shining black; wings strongly dusky except basal portions subhyaline ; veins and stigma deep brown; tegula blackish ; legs black (or piceous), fore tibia reddened or yellowish brown anteriorly; metasomal terga and sterna red except basal portion of 1 st tergum blackened.

Inner eye margins only slightly converging below, so that the face broad on lower portion ; malar space broad, about two-thirds as broad as basal width of mandible in the middle, broadened posteriorly; distance between eye and clypeus broad, slightly broader than width of mid ocellus, which is only slightly smaller than posterior ones ; clypeus rather broadly flat ; supraclypeal area well convex, upper portion more or less abruptly slanting above, slightly dilated laterally ; ratio of ocellocular distance to postocellar distance to ocelloccipital distance as $5.5: 3.5: 6.0$. Mesoscutum well convex; scutellum also well convex; metanotum conically convex in the middle, although weakly so ; propodeal enclosure large, slanting but almost all dorsal, outer margins slightly outwardly convex ; precoxal carina on lower portion of mesepisternum strong, rather long. Metasoma with 1st tergum 
rather large, well convex ; 2nd only slightly depressed at the base.

Head nearly smooth, very shining, with microscopical, sparse punctures even on frons and vertex ; clypeus longitudinally lineolate, especially in the middle ; mesoscutum smooth and shining like head, sparsely, somewhat distinctly punctate ; scutellum more densely, subrugoso-punctate ; propodeal enclosure shining, nearly smooth or microscopically lineolate ; propodeum outside enclosure rather weakly, not very densely punctate on shagreened and weakly shining ground ; upper portions of pre- and meso-episternum weakly, more or less densely punctate. First tergum weakly, more or less densely punctate on microscopically shagreened ground ; 2nd and 3rd more strongly punctate ; apical margins of 1 st and following terga impunctate, especially broadly so on 2nd and 3rd.

Hairs very sparse ; apical margin of tubercle and space next to it densely covered with snowwhite, short hairs ; hairs on propodeum white, not specially dense on lateral face ; hairs on inner side of hind tibia conspicuous, dense, appressed, glistening silver white ; hairs on metasoma fuscous or blackish including those on 6th segment.

Male : Relative head measurements : width, 40.0 ; length, 38.0 ; upper interocular distance, 19.0 ; width of face, 23.5 ; lower interocular distance, 17.0 ; eye length, 30.5 ; length of clypeus, 17.5 ; length of malar space in the middle, 5.0.

Differs from female as follows : head with following markings pale yellow : narrow, median line on clypeus, line on paraocular area lateral to clypeus (sometimes evanescent), spot on labrum, and line on mandible ; all femora often with small pale yellow spot at each apex ; malar space elongate, about equal to basal width of mandible ; scape long; flagellum long, with 1st segment a little longer than broad, 2nd broader than long, 3rd about as long as broad, 4th and following segments longer than broad; 3rd sternum either normal or with a pair of weak to very strong, conical projections (3rd sternum normal in 39 out of 60 specimens) ; 4th sternum nomral ; 5th sternum with apical fringe of long, curled, fuscous hairs.

TYPE MATERIAL : Holotype female (BISHOP 13885), 4 paratopotype females and 27 paratopotype males, Mt. Kaindi, 2,388 m, Morobe District, 14-26. vii. 1982 (Y. Hirashima) ; 3 paratopotype females and 8 paratopotype males, same data as holotype (0. Tadauchi) ; 26 paratopotype females and 24 paratopotype males, ix. 1969 (Y. Hirashima). Most of them were collected on the flowers of Rubus spp.

Distribution : Papua New Guinea (Mt. Kaindi).

\section{Palaeorhiza eugenes, new species}

This is superficially very similar to eumorpha, but is separated from it by the following characters :

Female : Relative head measurements : width, 41.0 ; length, 36.0 ; upper interocular distance, 23.0 ; width of face, 27.5 ; lower interocular distance, 21.0 ; eye length, 28.5 ; length of clypeus, 15.5 ; length of malar space in the middle, 3.5 .

Inner eye margins more converging below, so that lower portion of face narrower; face less shining, frons nearly dull ; malar space a little longer ; clypeus more strongly convex, densely longitudinally lineolate with stronger and denser punctures ; upper portion of supraclypeal area more dilated' with sharp lateral margins ; paraocular area densely lineolate, with denser, longitudinal punctures ; frons shagreened ; ocelli smaller, more widely separated to each other (width of median ocellus, 6.0 in eumorpha, 5.0 in eugenes ; distance between mid and post (lateral) ocellus, 2.0 in eumorpha, 3.5 in eugenes). Mesoscutum strongly, densely rugoso-punctate ; scutellum flat, densely rugoso-punctate ; metanotum not weakly convex, but not conically elevated in the middle; propodeal enclosure duller ; pre- and mesepisternum more strongly and densely punctate. First tergum smooth (microscopically 
shagreened in eumorpha), with sparser punctures (which are very small as in eumorpha). Hairs on head and thorax longer and denser ; hairs on propodeum grey, those on lateral face longer, sparser ; hairs on inner side of hind tibia less conspicuous.

M ale : Relative head measurements : width, 41.0 ; length, 36.0 ; upper interocular distance, 22.0 ; width of face, 25.5 ; lower interocular distance, 18.0 ; eye length, 29.0 ; length of clypeus, 17.5 ; length of malar space in the middle, 4.5 .

Yellow markings on head more developed (mark on clypeus long, reversed Y-shaped ; longitudinal mark on paraocular area broader ; stripe on mandible also broader; and a spot on labrum larger) ; head and thorax more strongly and densely punctate, as in female ; 3rd sternum normal, rarely with a pair of weak elevations; 4th sternum with a pair of weak elevations in larger specimens.

TYPE MATERIAL: Holotype female (BISHOP 13886), 3 paratopotype females and 6 paratopotype males, Mt. Kaindi, 2,360 m, on Rubus sp., 24-25. ix. 1969 (Y. Hirashima) ; 5 paratopotype females, 1112. ix. 1969 (Y. Hirashima) ; 4 paratopotype females and 1 paratopotype male, viii. 1969 (Y. Hirashima) ; 1 paratopotype female, 14-26. vii. 1982 (Y. Hirashima).

Distribution : Papua New Guinea (Mt. Kaindi).

\section{Palaeorhiza eugenoides, new species}

This is a sibling species of eugenes, and is only separable from the latter by the following characters :

Female : Relative head measurements: width, 39.0 ; length, 35.0 ; upper interocular distance, 21.5 ; width of face, 26.5 ; lower interocular distance, 22.0 ; eye length, 27.0 ; length of clypeus, 15.0 ; length of malar space in the middle, 4.5 .

Inner eye margins subparallel or only slightly converging below, so that face broader on lower portion ; malar space slightly longer ; face less lineolate and shagreened, more shining ; clypeus, supraclypeal area and lower portion of paraocular area more convex ; space between eye and clypeus broader ; impunctate, smooth apical margins of 1 st to 3rd terga narrower.

M ale : Relative head measurements : width, 38.5 ; length, 35.0 ; upper interocular distance, 21.0 ; width of face, 25.0 ; lower interocular distance, 21.0 ; eye length, 27.0 ; length of clypeus, 15.5 ; length of malar space in the middle, 5.5.

Inner eye margins much less converging below, nearly subparallel ; malar space slightly longer, about as long as basal width of mandible ; space between eye and clypeus broader ; scape dilated and excavated behind at apex (scape normal and slender in eumorpha, nearly normal or only slightly robust in eugenes) ; 3rd and 4th sterna each with a pair of rather distinct elevations ; yellow marking on head much reduced (clypeus alone with a short pale yellow line).

TyPe MAterial : Holotype female (BISHOP 13887), 5 paratopotype females and 1 paratopotype male, Keglsugl, 2,700 m (Mt. Wilhelm), 11-13. viii. 1969 (Y. Hirashima), 1 female was taken on Rubus sp. ; 1 paratopotype female, 31. vii. 1982 (Y. Hirashima).

Distribution : Papua New Guinea (Mt. Wilhelm).

\section{Palaeorhiza senilis, new species}

This is slightly smaller than eugenes and eugenoides, and is easily separable from them by the head and malar space shorter, the inner eye margins more converging below, and the thorax with distinct snow-white hairs.

Female : Length about $9 \mathrm{~mm}$. 
Relative head measurements : width, 40.0 ; length, 33.0 ; upper interocular distance, 23.0 ; width of face, 26.0 ; lower interocular distance, 19.0; eye length, 27.0 ; length of clypeus, 13.8 ; length of malar space in the middle, 2.0.

Inner eye margins distinctly converging below, so that lower portion of face narrower than in eugenes, much narrower than in eugenoides and eumorpha; malar space less than half of basal width of mandible, shortest in the eumorpha-group; clypeus and supraclypeal area largely flat or only slightly elevated ; clypeus densely, microscopically shagreened, rather dull, with sparse, weak punctures; upper portion of supraclypeal area broad, dilated laterally, gently slanting above ; ocelli rather small ; ratio of ocellocular distance to postocellar distance to ocelloccipital distance as $\mathbf{7 . 0}$ : $3.0: 5.0$.

Mesoscutum well convex, densely, rather strongly rugoso-punctate (nearly as in eugenes); scutellum flat, densely rugoso-punctate, punctures distinctly weaker than those on mesoscutum ; propodeal enclosure large, well dorsal, microscopically shagreened, weakly shining ; sides of thorax well punctate.

Metasomal terga smooth, shining, well punctate ; punctures on 1st very weak, sparse, those on 2nd stronger, those on 3rd and 4th large ; 1st and following terga each with a broad glabrous apical margin ; hairs on apical portion of metasoma fuscous as usual for the eumorpha-group.

Wings dusky, basal portions subhyaline.

Male : Relative head measurements : width, 35.5 ; length, 31.0 ; upper interocular distance, 20.0 ; width of face, 22.0 ; lower interocular distance, 15.2 ; eye length, 24.5 ; length of clypeus, 13.5 ; length of malar space in the middle, 2.8 .

Head with evanescent pale yellow markings as follows : small, reversed T-shaped mark on clypeus (median line evanescent), and short, narrow lines on mandible and lower paraocular area ; anterior face of fore tibia yellowish brown. Inner eye margins distinctly converging below (similar to eugenes) ; malar space and space between eye and clypeus broad ; scape normal, only slightly dilated apically; flagellum with 1st segment slightly longer than broad and as long as 3rd, 2nd broader than long, 4th and following segments longer than broad. Metasoma with 1st tergum low ; 2nd distinctly convex medially and depressed basally ; 3rd and 4th terga each with a pair of longitudinal, rather weak elevations medially.

TyPe MATERIAL : Holotype female (BISHOP 13888), Keglsugl, 2,600 m, Mt. Wilhelm, Chimbu District, 31. vii. 1982 (Y. Hirashima) ; paratype male, Mt. Giluwe, 2,700 m, Southern Highland District, 11. viii. 1982 (Y. Hirashima).

Distribution : Papua New Guinea (Mt. Wilhelm and Mt. Giluwe). 